\title{
銅のアノード精製とその電解について*
}

（昭和 32 年度渡辺賞牌受賞）

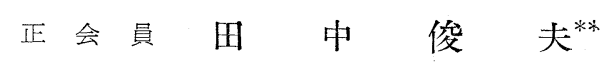

\section{Anode Furnace Refining and Electrolysis of Copper}

Toshio TANAKA

At Mitsubishi Osaka Refinery, the study and experiments of anode furnace refining and electrolysis of refined anodes had been operated since 1950. When the increase of the copper production to 2000 tons from 1500 tons per month was decided at Osaka Refinery in 1954, we adopted this electrolytic process according to the results of our study.

Therefore, the furnace refining installation was constructed at Naoshima Smelter in December 1954, and the electrolytic refining of the refined anodes has been operated at Osaka Refinery since February 1955. It was the first practice in japan.

Moreover we enlarged the production capacity of both of Naoshima and Osaka to 3000 tons per month in November 1957. Since that time our plants have been operated so smoothly and effectively.

In this report the results of the comparison experiments with blister anodes and refined anodes, the practical operating data and the effects of the enlarging construction are discussed.

1. 緒

\section{言}

銅電解精製に和いて転师より産出した粗銅を反射灯に て精製した後アノードとして電解することは諸外国に㧈 いては古くから行われて和り常道之考光られている。乙 かし本邦に括いてはわが大阪製徚所が昭和30年に始めて 採用して以後交だ活とんど行われていない。

筆者らはか权てからこれに関心を持つていたので昭和 25 年 6 月よりこれの研究を開始していたところ, 翌年 9 月日本鉱業会の冶金専門委員会でもこの問題が採り上げ られたので管者らる同委員会に参加し全面的に研究に協 カした。同委員会としての研究は一応昭和27年11月に終 了したが，筆者らはその後も研究を続けてその有利性を 確認することが出来た。すでに昭和 26 年 12 月以来残基銅 鋳返えしのアノードは，すべていわゆる精製アノードと して試験操業を行つていたので等者らの研究推進に大い に役立てることが出来た。かくして全面的な精製アノー ド電解法の採用を企図していたところ，たまたま昭和 29

* 昭和 33 年 4 月 15 日受理

** 三菱金属鉣業株式会社直島製㤓所副脣
年大阪製䊂所の電解能力増強の必要が生じたのでこれが 動機となり本法の採用を見るに到つた。

すなわち起業方針としては大阪製谏所の電解槽を增設 せずと少ない起業工事費をるつて電気銅月座 1500 より $2000 t$ 亿增強するとともに, 製鋉費の軽減, 実収率の向 上，抢よび製品品質の向上等を計り諸外国製鍊所と比較 して遜色のない慗鍊所とすることにあつた。この方針に まつ代く合致するものとして精製アノード電解法の採用 が決定されたのである。このため直島製煉所に精製炬を 新設することになり，昭和 29 年 4 月工事を開始した。そ 乙て同年 9 月末に完成，10月よりアノード精製の試験操 業を開始し翌年(昭和30年) 1 月上り本格的精製操業に大 つた。これに伴つて大阪製眯所では 2 月ょり本格的な精 製アノード電解が行われるようになつた。このようにし てその後予期以上の效果を挙げ順調な操業を続けていた ところ, さらに罟和 31 年 12 月直島製谏所の製鍊能力をア ノード月应 $3000 \mathrm{t}$ 飞, 大阪製煉所の電解能力を電気銅月 産最大 $3000 \mathrm{t}$ 亿増强することになつた。工事は昭和 32 年 11月に完成しここに本邦最大の製鉬設備を備兄るに到つ た。相つぐ増産工事が少額の工事費と短かい工事期間で 


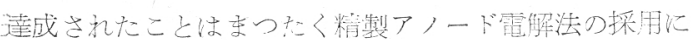
活かならず，その䒨果は高く評伴されている。

\section{2. 研究事項の大要}

\section{$2 \cdot 1$ アノード精製工程に関する研究}

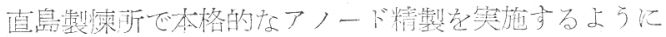

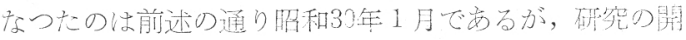

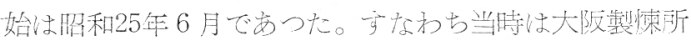

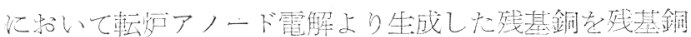

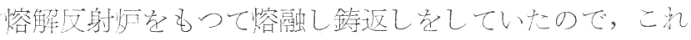

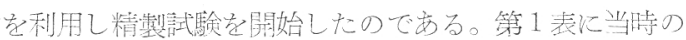
精製却挴の 1 例を示与。

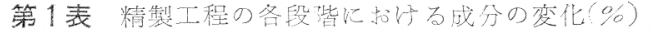

\begin{tabular}{|c|c|c|c|c|}
\hline & 残 基 銅 & 酸 优 绶 & 逷 元 後 & 精製 7 , 一 \\
\hline $\begin{array}{l}\mathrm{Cu} \\
\mathrm{S} \\
\mathrm{O} \\
\mathrm{Pb} \\
\mathrm{As} \\
\mathrm{Sb} \\
\mathrm{Bi} \\
\mathrm{Fe} \\
\mathrm{Ni} \\
\mathrm{Zn} \\
\mathrm{Au} \\
\mathrm{Ag} \\
\mathrm{Se}+\mathrm{Te} \\
\mathrm{Al} \\
\mathrm{Al}\end{array}$ & $\begin{array}{l}98.20 \\
0.030 \\
0.350 \\
0.132 \\
0.050 \\
0.100 \\
0.005 \\
0.030 \\
0.140 \\
0.007 \\
0.00670 \\
0.2089 \\
0.050 \\
0.010 \\
7.60\end{array}$ & $\begin{array}{l}98.60 \\
0.010 \\
0.470 \\
0.099 \\
0.046 \\
0.050 \\
0.005 \\
0.009 \\
0.135 \\
0.006 \\
0.00676 \\
0.2253 \\
0.048 \\
0.007 \\
8.640\end{array}$ & $\begin{array}{l}99.02 \\
0.033 \\
0.150 \\
0.088 \\
0.040 \\
0.055 \\
0.005 \\
0.009 \\
0.130 \\
0.006 \\
0.190689 \\
0.227 \\
0.042 \\
0.007 \\
8.84\end{array}$ & $\begin{array}{l}99.08 \\
0.008 \\
0.120 \\
0.078 \\
0.040 \\
0.055 \\
0.005 \\
0.009 \\
0.133 \\
0.005 \\
0.00680 \\
0.2290 \\
0 . C 42 \\
0.006 \\
8.83\end{array}$ \\
\hline 揇 & 量 $39.6 \mathrm{t}$ & $\begin{array}{c}\text { 肚問 } 2 \mathrm{hrs} \\
\text { 五力 } 1 \mathrm{~kg} / \mathrm{cm}^{2} \\
\left(1^{\prime \prime} \mathrm{Cot}^{2}\right) \\
\text { 温度 } 1200^{\circ} \mathrm{C}\end{array}$ & $\begin{array}{l}\text { 菘買 } 75 \mathrm{~kg} \mathrm{t} \\
\text { 温度 } 1150^{\circ} \mathrm{C}\end{array}$ & 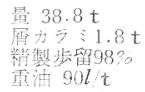 \\
\hline
\end{tabular}

\section{（1）不純物の恋化}

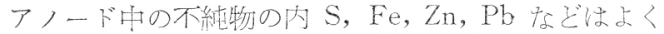
酸化除土されている。李た $\mathrm{Ni}$ ， Bi，Se，Teなどは唒参 化汶して蜰い拱抗力の市ることを示している。

\section{（2）精製工程における金属組織の变化}

第1図に精製過程における金属組織の变化が示されて いるが，これによつて酸化，還元の状熊起知ることが出 来る。

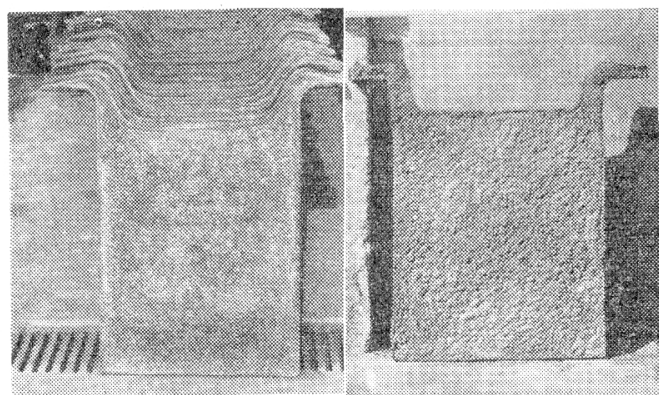

（1）老面精製アノード

軩炉アノート

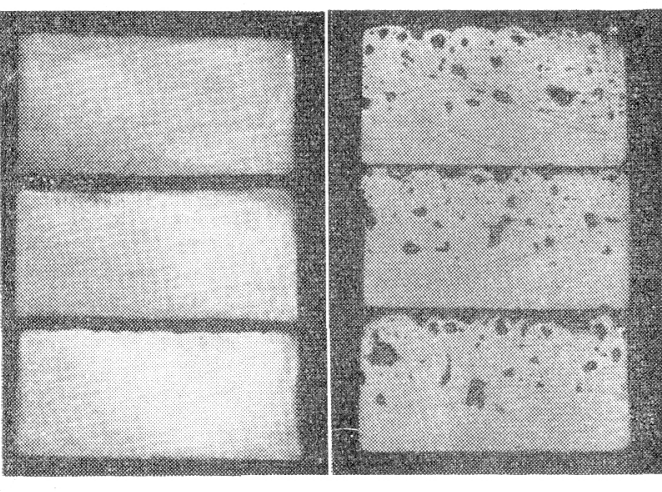

(2) 断面精製了, - - b

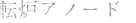

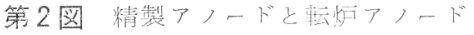

の外程上の比烄

(3)外钼，比重に及ぼす影響

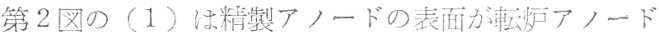

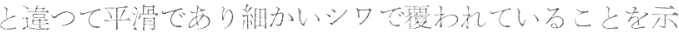
している。票た断面は（2）のよらに精製アノードには 约泡はまつたくたく非常に繳密である

比重は檕灯アノード7.6亿対して精整アノードは8.8と 上杽している。

$2 \cdot 2$ 精製アノードの電解咸績に及ぼす影響

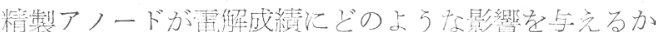

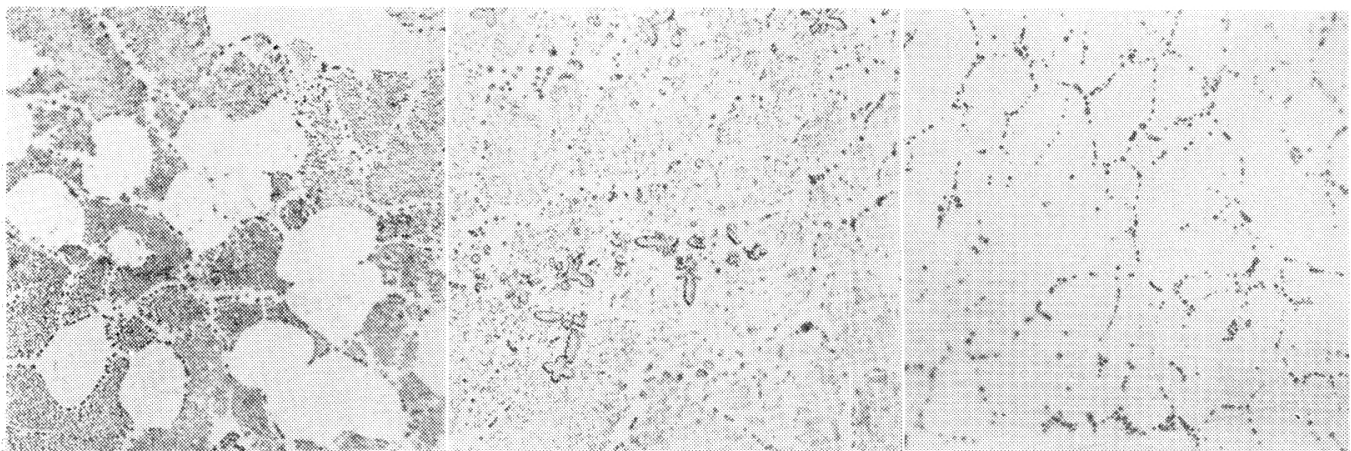

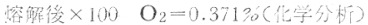

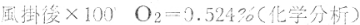

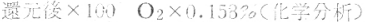

第1図 精製二程に扣ける組織の变化 


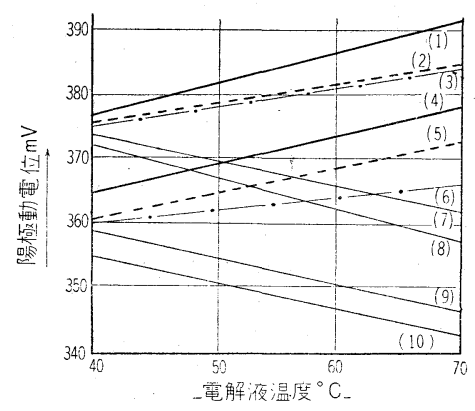

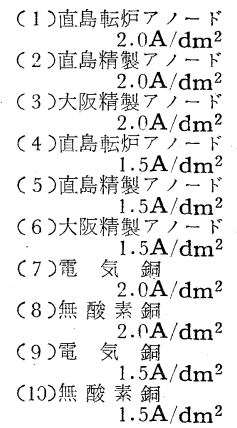

第 3 图 各種アノードの陽極動電位

(電解液 : $\mathrm{Cu} 40 \mathrm{~g} / l, \mathrm{FA} 175 \mathrm{~g} / l$ )

を知るためにつぎのような実験を行つた。

\section{（1）槽電圧に及ぼす影響}

槽電圧は液抵抗が一定であれば陽極動電位と㓌極動電 位との差で決まる。陰極動電位はいずれも純粋な析出銅 を除極として使用するのでほとんど差がない訳である。 陽極動電位の大小で汪とんど槽電圧は決定される。それ で陽極動電位を測定すればアノード種別の槽電圧に及注 す影響を知ることが出来る訳である。

実験には第 2 表に示す通りの直島転炉アノード，直島 精製アノード，大阪精製アノード(残基銅鋳返アノード) 電気銅执よび無酸素銅を拈の扔のアノードとして陽極動 電位の測定を行つた。その測定結果は第 3 困の通りであ る。

この測'定結果よりつぎの事がい党る。

a）電添密度と温度が同一であれば転览アノードの動 電位がもつとも高く精製アノード，䨖気銅，無酸素銅の 順に低くなつている。つまり液抵抗による電圧降下が同 一であれば槽圧はこの順序になる訳である。

b）温度勾配に転吙アノードと精製アノードは正で， 電気銅と無酸素銅は負となつている。また転炉アノード の温度勾配 $0.4 \mathrm{mV} /{ }^{\circ} \mathrm{C}$ に対し精製アノードは $0.3 \mathrm{mV} /{ }^{\circ} \mathrm{C}$ となつて扔りわずかであるが少ない值を示している。い ずれにしても両方とも電解液温が上昇する粗陽極動電位 は高くなる訳である。以上の通り，陽極動電位として性 質はわずかではあるが精製アノードの方が転炉アノード より優れているといえる。しかし実際的に精製アノード を便用して槽電圧を下げるにはむしろ表面の平滑なこ と, 比重の大きいことを利用して極間距離を狭くして液 抵抗を少なぐすることが效果的である。

\section{（2）不純物の陽極動電位に及ぼす影響}

合金あるいは化合物として多くの種類の元素を含む粗 銅は純銅に比べて電極電位が一般に高く，末た温度勾配 は正の傾问を持つている。これら不純物の影響について 行つた実験の内 2,3 主なものを概要説明する。

実験には棹銅と同質の銅地金（TPC）に不純物として $\mathrm{Ag}, \mathrm{Pb}, \mathrm{Ag}_{2} \mathrm{Se}, \mathrm{Cu}_{2} \mathrm{Se}, \mathrm{PbS}$ をそれぞれ必要量添加 してアノードを作製した。電解液は $\mathrm{Cu} 40 \mathrm{~g} / l, \mathrm{FA} 175 \mathrm{~g} / l$; 電流密度は $2.0 \mathrm{~A} / \mathrm{dm}^{2}$ の電解条件で陽極動電位の測定を 行つた。

a) $\mathrm{Ag}$ の影響 $: \mathrm{Ag}$ を単体として添加すると $\mathrm{Ag}$ は $\mathrm{Cu}$ と完全国溶体を造るので合金電位の一般原則に従つ て影響を与える。害際に使用されているアノード中の $\mathrm{Ag}$ は $\mathrm{Ag}_{2} \mathrm{Se}$ として含有されている場合が多いので $\mathrm{Se}^{2}$ の影響をらけた第6困のような電位を示すようになる。 温度勾配は TPC と等しい。(第 4 図参照)

b) $\mathrm{Pb}$ の影響 : 銅電解液は硫酸酸性硫酸銅液である ので $\mathrm{Pb}$ は電解液中では $\mathrm{PbSO}_{4}$ となり, 電解液に不溶 となる。このため陽極動電位は $\mathrm{Pb}$ の含有量が増すにし たがい高くなる訳である。温度勾配は TPC と等しい。 (第 5 図参照)

c) Se の影響 : Se は他のものと違つて陽極動電位を 下げる㗢さが㐫る。温度勾配は TPC と等しい。（第 6 図参照)

d) 硫化物の影響: $\mathrm{PbS}, \mathrm{Cu}_{2} \mathrm{~S}$ の存在はいずれも陽 極動電位を高める。温度勾配の TPC と等しいことはa) b)c）と同じである。(第7 図参照)

e) $\mathrm{O}_{2}$ の影響 : 無酸素銅 $\mathrm{O}_{2} 0.002 \%, 0.003 \%, 0.007$ \%) TPC $\left(\mathrm{O}_{2}\right.$ 0.04\%) 精製アノード $\left(\mathrm{O}_{2} \quad 0.15 \%\right)$ 転炬 アノード $\left(\mathrm{O}_{2} 0.32 \%\right)$ について温度勾配を求め図示する と第 8 図のようになり一つの連続した傾向を示した。a） 〜d）の不純物は温度勾配には影響を与兄ていないので， この一つの傾间は $\mathrm{O}_{2}$ が影響していることを示している ように思われる。 $\mathrm{O}_{2} 0.02 \%$ 以下では負でこれ以上では 正の温度勾配となつている。

以上の不純物に関する実験によつて精製アノードが転: 炉アノードより陽極動電位の低い理由を明らかにするこ とが出来た。

\section{（3）電流効率に及ぼす影響}

精製アノードは転炉アノードの表面のような四凸和よ び電解液に不溶性のクラストなどがなく表面から均一に

第 2 表 供試アノードの分析結果 ( $\mathrm{Au}, \mathrm{Ag}: \mathrm{g} / \mathrm{t}$ その他：\% )

\begin{tabular}{|c|c|c|c|c|c|c|c|c|c|c|c|c|c|}
\hline 別 & $\mathrm{Cu}$ & $\mathrm{Au}$ & $\mathrm{Ag}$ & $\mathrm{S}$ & $\mathrm{Pb}$ & $\mathrm{Ni}$ & $\mathrm{Fe}$ & As & $\mathrm{Sb}$ & $\mathrm{Bi}$ & $\mathrm{Se}$ & $\mathrm{Te}$ & $\mathrm{O}_{2}$ \\
\hline 柜アノード & 98.6 & 90 & 3000 & 0.003 & 0.25 & 0.10 & $0.01 \div$ & 0.05 & 0.04 & 0.004 & 0.03 & 0.02 & 0.32 \\
\hline 直島精製アノード & 99.2 & 50 & 2000 & 0.008 & 0.22 & 0.09 & 0.003 & 0.04 & 0.03 & 0.003 & 0.04 & 0.02 & 0.12 \\
\hline 大阪精製アノード & 99.1 & 90 & 3000 & 0.001 & 0.22 & 0.10 & 0.005 & 0.02 & 0.02 & 0.004 & 0.03 & 0.02 & 0.12 \\
\hline 電銅 & 99.99 & 0.1 & 8 & 0.0006 & - & - & 0.0005 & 0.0001 & 0.0002 & - & - & - & \\
\hline 無 酸 素 銅 & 99.99 & - & - & 0.0006 & - & - & - & - & - & - & & - & 0.00 \\
\hline
\end{tabular}




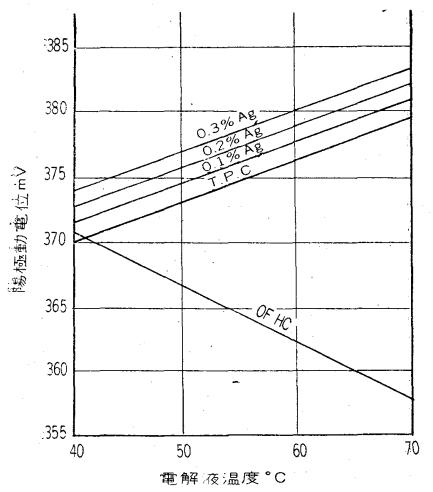

第4図 $\mathrm{Ag}$ 添加の陽極動電位 に及活す影響

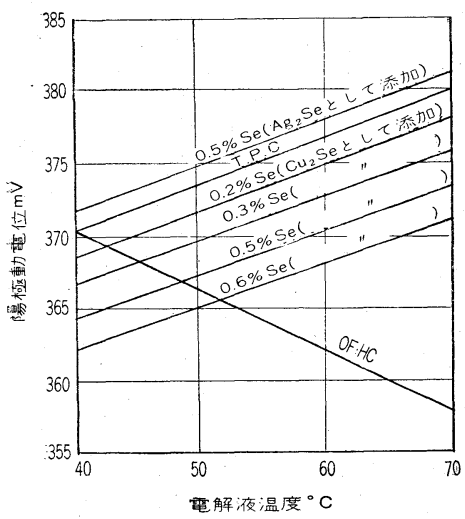

第6 図 Se 添加の陽極動電位 に及洼す影響

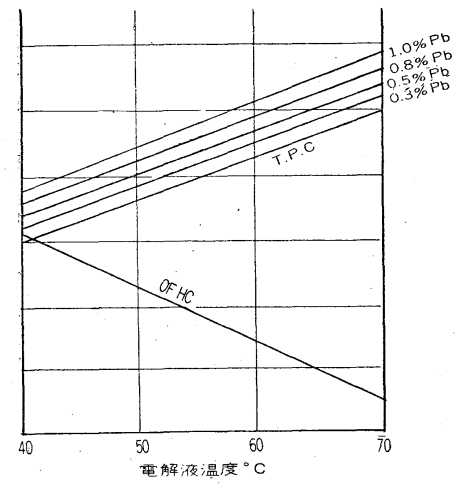

第 5 図 $\mathrm{Pb}$ 添加の陽極動電 位に及活す影響

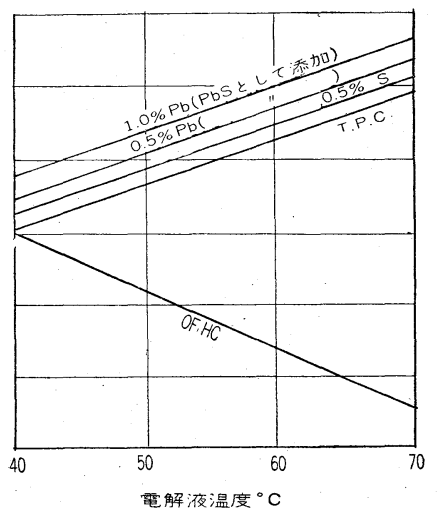

第 7 図 硫化物添加の陽極動 電位に及注す影響
溶解されるので, 電解条件が同じで あれば䉓流勃率は精製アノードの方 が高い訳である。これを定量的に知 るため工場策験を行つたので，その 結果を概要説明する。

この実験に用いたアノードの主要 成分を第 3 表に, 電解条件を第 4 表 に, 実験結果の電流效率を第 5 表に 示す。

第 5 表により精製アノードの電流 效率は常に転炉アノードより高くそ の特長をよく知ることが出来る。

\section{（4）陽極スライム粒度に及ぼす}

\section{影響}

すでに述べたように精製アノード は表面が平滑で全体が緻密であるの で陽極スライムも自然微細となる

第 4 表 電解条件

\begin{tabular}{|c|c|}
\hline 項 & 条 \\
\hline 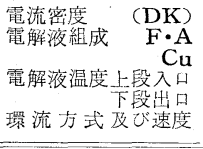 & 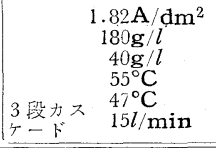 \\
\hline 項 & 条 \\
\hline 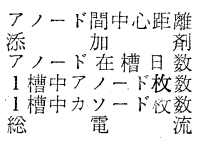 & $\begin{array}{r}135 \mathrm{~m} / \mathrm{m} \\
60 \mathrm{~g} / \mathrm{t}, \mathrm{Cl} 10 \mathrm{mg} / l \\
7,8,8 \mathrm{日} \\
33 \text { 枚 } \\
34 \text { 枚 } \\
6000 \mathrm{~A}\end{array}$ \\
\hline
\end{tabular}

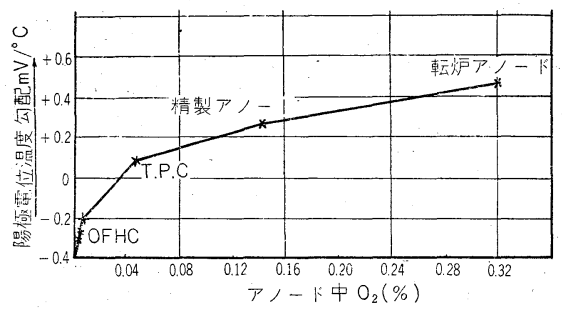

第 8 図 陽極電位温度勾配とアノード 中 $\mathrm{O}_{2}$ 含有量との関係

第 3 表 アノード主要成分 ( $\mathrm{Au}, \mathrm{Ag}: \mathrm{g} / \mathrm{t}$, その他:\%)

\begin{tabular}{|c|c|c|c|c|c|c|c|}
\hline 種 & 別 & $\mathrm{Au}$ & $\mathrm{Ag}$ & $\mathrm{Cu}$ & $\mathrm{Pb}$ & $\mathrm{Ni}$ & As \\
\hline \multicolumn{2}{|c|}{$\begin{array}{l}\text { 転炉アノード } \\
\text { 精製アノード }\end{array}$} & $\begin{array}{l}45.5 \\
73.8\end{array}$ & $\begin{array}{l}1542 \\
1875\end{array}$ & $\begin{array}{l}98.11 \\
98.99\end{array}$ & $\begin{array}{l}0.532 \\
0.271\end{array}$ & $\begin{array}{l}0.088 \\
0.131\end{array}$ & $\begin{array}{l}0.036 \\
0.059\end{array}$ \\
\hline 種 & 別 & $\mathrm{Sb}$ & $\mathrm{S}$ & & S & $\mathrm{O}_{2}$ & Insol \\
\hline 転炏 & - & $\begin{array}{l}0.043 \\
0.018\end{array}$ & & & $\begin{array}{r}.043 \\
.009\end{array}$ & $\begin{array}{l}0.40 \\
0.10\end{array}$ & $\begin{array}{l}0.142 \\
0.050\end{array}$ \\
\hline
\end{tabular}

がこれについて行つた測定結果を第 6 表に示した。こ の表より精製アノードスライムの微細なことをよく知る ことが出来る。

第 5 表 電 流、效 率 (\%)

\begin{tabular}{l}
\hline \multicolumn{5}{c|}{ 第 1 回仕上第 2 回仕上第 3 回仕上 } & 平 \\
\hline
\end{tabular}

第6 表 陽極スライム粒度分布

(\%)

\begin{tabular}{l}
\hline mesh \\
種 別
\end{tabular}




\section{3. 設 偖 の 概 要}

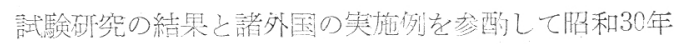
に新設した主要設備は概要つぎの通りである。

\section{$3 \cdot 1$ 直島製煉 所}

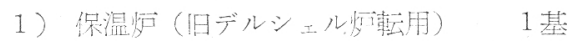

容量 $40 \mathrm{t}$

型式 水限户筒型。3 $360^{\circ}$ 回転式

外法 $8500 \mathrm{~mm}$ (長) $\times 2700 \mathrm{~mm}$ (径)，七儿鋼板 $19 \mathrm{~mm}$

内径 $2140 \mathrm{~mm}$

煉瓦 䏱部はコルハートブラック，煙渞バーナ側はマ グネシヤ懒瓦

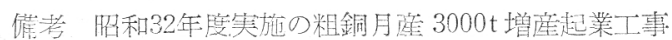
によって不要となり廃上。

2) 精慗炉 2 基 (内1基性予備)

旧デルンェル颀軽月，七ルは新品改造

容量 $30 \mathrm{t}$

型式 水篮筒刑， $360^{\circ}$ 回転式

外法 $5339 \mathrm{~mm}$ (長) $\times 2700 \mathrm{~mm}$ (径)，七几鋼板 $19 \mathrm{~mm}$ 内径 $2040 \mathrm{~mm}$

煉瓦 全部クロマグ楝瓦。厚さ250mm

装入口 $60 \mathrm{cmm} \times 300 \mathrm{~mm}$

タップホール $60 \mathrm{~mm} \emptyset$

バーナー L.B 30 改造型（中外桠丁.業製）

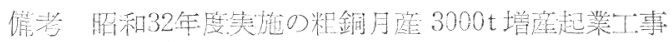

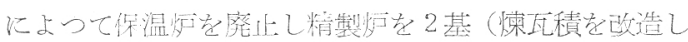
$40 \mathrm{t}$ 容量之寸る) 交互俱用与るようにならた。現在は常

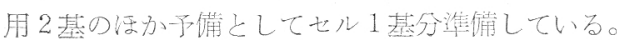

3) 余唯ボイラー 1 基

型式 HK-C 型承管式 (平川銅工製)

伝熱面積 $43 \mathrm{~m}^{2}$

蒸汽発生量 $1 \mathrm{t} / \mathrm{hr}$

制限压力 $16 \mathrm{~kg} / \mathrm{cm}^{2}$

管用压力 $5 \mathrm{~kg} / \mathrm{cm}^{2}$

$$
\text { 4) ポーリンダ用タレーン } 1 \text { 基 }
$$

掦 ‘ 程 $6.1 \mathrm{~m}$

巻上速度 $8.5 \mathrm{~m} / \mathrm{min}$

走行速度 $50 \mathrm{~m} / \mathrm{min}$

ス 오 ン $7.7 \mathrm{~m}$

モーター $5 \mathbb{P} \cdot 3 \mathbb{P}$

5) 矢の他

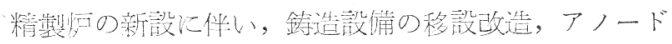
取扱の機城化，アノード含軍の移設等付带設備の改良工 事老行つた。

\section{$3 \cdot 2$ 大阪製煉所}

直流電源として従来上り支つた $750 \mathrm{~kW}(135 \mathrm{~V}, 5555$ A) 子 $900 \mathrm{~kW}(150 \mathrm{~V}, 6000 \mathrm{~A})$ の 2 台の電動発電機茷

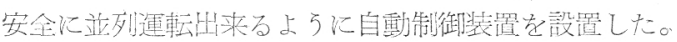
委た從来のコンダクターは $6000 \mathrm{~A}$ 通電の設計のものて めつたので，こ礼を $9000 \mathrm{~A}$ 通電䗇るようにコンダク タ一の容量を增玑した。

\section{4. 操業法の概要}

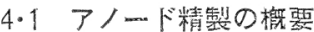

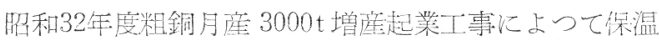

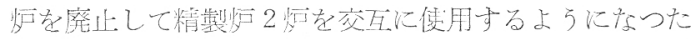
ので，この操業法について説明する。

転夘粗銅の基淮什上りは S $0.03 \% ， \mathrm{O}_{2} 0.45 \%$ として いる。8tレードルにて直接䊉製岁汇装入する。粗銅量 40t、飞達すればカラミ引党して加熱し温度を上げる。

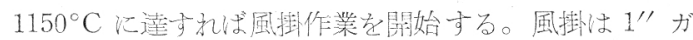

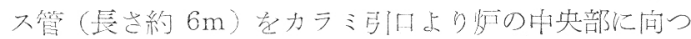

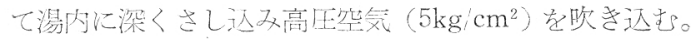
炣内は酸化焰之寸る。風排の終点は $\mathrm{S} 0.01 \%$ 以下, $\mathrm{O}_{2}$

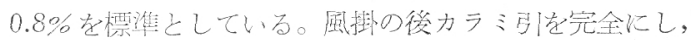
再び $1150^{\circ} \mathrm{C}$ 亲で加熱する。ポーリングは炣内を還元気 圈とし生松丸太を用い2 回に分けて行ら。その仕上りは $\mathrm{S} 0.01 \%$ 以下， $\mathrm{O}_{2} 0.1 \%$ 老標淮としている。

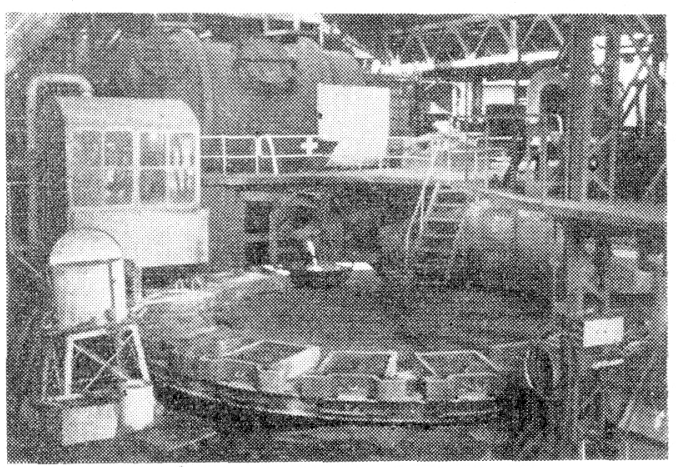

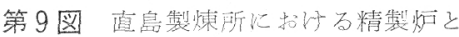
ウォル力式鋳造機

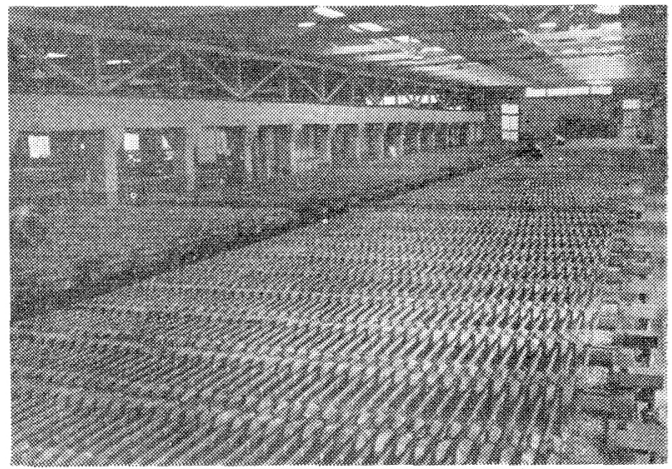

第10図大阪製煤所に扎子電解室の一部 
鋳造は湯温 $1120^{\circ} \mathrm{C}$, モールド温度 $120^{\circ} \mathrm{C}$ を基潐とし

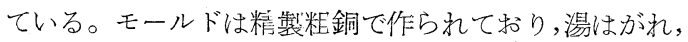
焼付を防止するためにスプレーにて骨灰をモールド面に 吹き付けている。鋳造運転手は精製炉上りの湯出し， レ 一ドルの算降調節，鋳造機の回転等を 1 人で行つている。 アノードの吊上げ拈よび水洗は鏏造機と連動し完全な自 動運転装置となつている。アノード重量は $155 \mathrm{~kg} \pm 5 \mathrm{~kg}$ となつている。

第 7 表

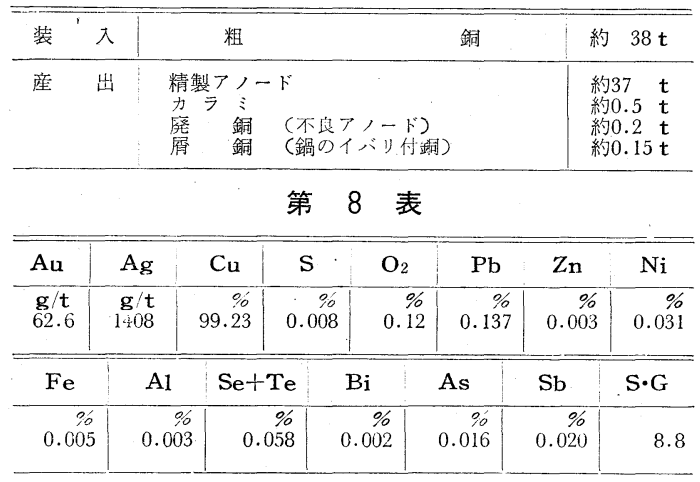

第 9 表

\begin{tabular}{|c|c|c|c|c|c|c|}
\hline 項 & $\mathrm{Cu}$ & $\mathbf{S}$ & $\mathrm{O}_{2}$ & $\mathrm{~Pb}$ & $\mathrm{Ni}$ & $\mathrm{Se}+\mathrm{Te}$ \\
\hline 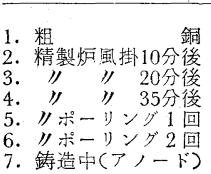 & \begin{tabular}{r|}
$\%$ \\
98.79 \\
98.80 \\
98.83 \\
98.84 \\
99.31 \\
99.46 \\
99.45
\end{tabular} & $\begin{array}{r}\% \\
0.030 \\
0.030 \\
0.023 \\
0.015 \\
0.008 \\
0.008 \\
0.008\end{array}$ & $\begin{array}{r}\% \\
0.478 \\
0.484 \\
0.542 \\
0.774 \\
0.227 \\
0.113 \\
0.115\end{array}$ & $\begin{array}{r}\% \\
0.222 \\
0.218 \\
0.216 \\
0.212 \\
0.203 \\
0.202 \\
0.201\end{array}$ & $\begin{array}{r}0 \% \\
0.123 \\
0.122 \\
0.120 \\
0.116 \\
0.114 \\
0.112 \\
0.1112\end{array}$ & $\begin{array}{r}\% \\
0.049 \\
0.047 \\
0.045 \\
0.044 \\
0.044 \\
0.044 \\
0.045\end{array}$ \\
\hline
\end{tabular}

第 10 表

\begin{tabular}{|c|c|c|c|c|c|c|}
\hline 別 & $\mathrm{Cu}$ & $\mathrm{S}$ & $\mathrm{Pb}$ & $Z_{\mathbf{n}}$ & $\mathrm{Ni}$ & $\mathrm{Fe}$ \\
\hline 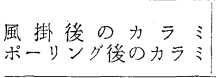 & $\begin{array}{r}\% \\
33.61 \\
34.07\end{array}$ & $\begin{array}{r}\% \\
0.06 \\
0.23\end{array}$ & $\begin{array}{r}7 \% \\
7.59 \\
10.00\end{array}$ & $\begin{array}{r}\% \\
0.80 \\
1.40\end{array}$ & $\begin{array}{r}\% \\
0.51 \\
1.01\end{array}$ & $\begin{array}{r}\% \\
3.43 \\
4.74\end{array}$ \\
\hline 種 & Al & $\mathrm{Se}+{ }^{\prime}$ & & $\mathrm{Bi}$ & As & $\mathrm{Sb}$ \\
\hline 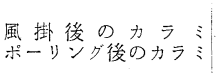 & $\begin{array}{r}\% \\
12.40 \\
10.13\end{array}$ & & $\begin{array}{l}\frac{1}{0} \\
\text { tr } \\
02\end{array}$ & $\begin{array}{r}\% \\
0.01 \\
0.01\end{array}$ & $\begin{array}{r}\% \\
0.08 \\
0.09\end{array}$ & $\begin{array}{r}\% \\
0.11 \\
0.04\end{array}$ \\
\hline
\end{tabular}

第 11 表

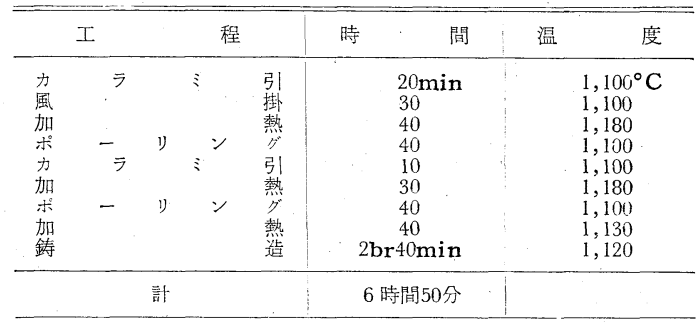

\section{$4 \cdot 2$ 電 解の 概 要}

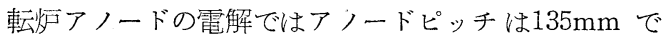
あつたが炤和30年度の起業工事で精製アノードの電解と なつたので $110 \mathrm{~mm}$ 亿短縮し 1 槽当りのアノード枚数は 33校より41枚に増加した。また昭和32年度の起業工事で アノードピッチをさらに短縮することにし現在新設の電 解室は $100 \mathrm{~mm}$ ピッチ(アノード45枚/槽) にして和り，

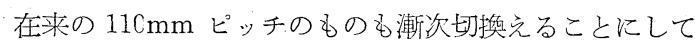
いる。

アノードピッチの短縮で電流を多く通すことが出来る 上うになり従来最大 $6100 \mathrm{~A}$ であつたものが，8500A の

第 12 表

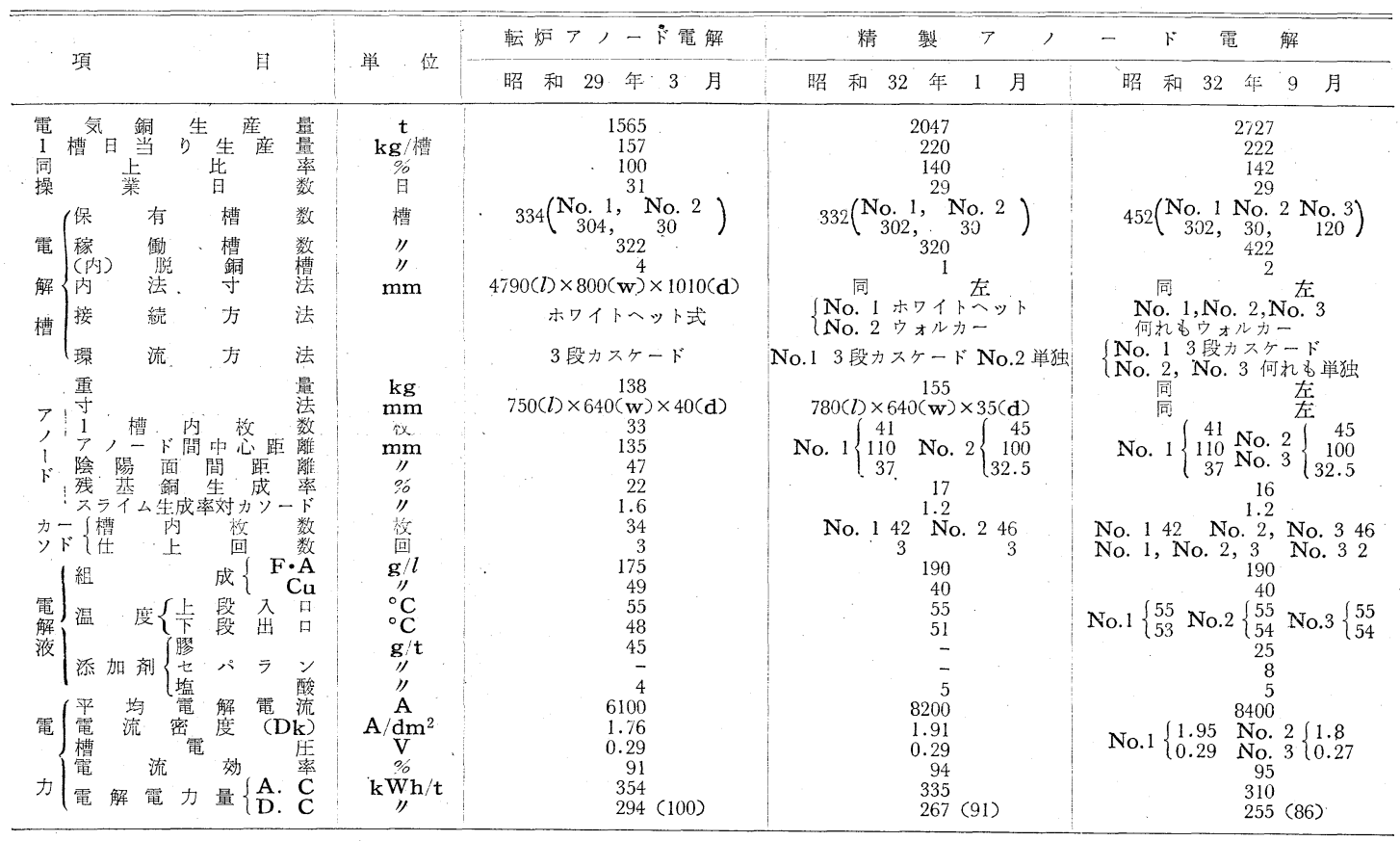


第 13 表

\begin{tabular}{|c|c|c|c|c|c|c|c|c|c|c|c|c|c|}
\hline 種 & $\mathrm{Au}$ & $\mathrm{Ag}$ & $\mathrm{Cu}$ & $\mathrm{Pb}$ & $\mathrm{Ni}$ & $\mathrm{Fe}$ & As & $\mathrm{Sb}$ & $\mathrm{Se}$ & $\mathrm{Te}$ & s & $\mathrm{O}_{2}$ & $\begin{array}{l}\text { 見掛 } \\
\text { 比重 }\end{array}$ \\
\hline 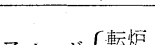 & $\mathrm{g} / \mathrm{t}$ & ${ }_{2080}^{\mathrm{g} t}$ & 98 & $0.35^{\%}$ & $0.15^{\%}$ & $0.02^{\%}$ & $0.05^{\%}$ & $0.10^{\%}$ & $0.04^{\%}$ & $0.02^{\%}$ & $\begin{array}{r}\% \\
0.028\end{array}$ & $\begin{array}{l}\% \\
0.40\end{array}$ & 7.10 \\
\hline アノード\{精製 & 62 & $\begin{array}{l}2080 \\
2100\end{array}$ & $\begin{array}{l}98.30 \\
99.10\end{array}$ & $\begin{array}{l}0.35 \\
0.18\end{array}$ & $\begin{array}{l}0.15 \\
0.13\end{array}$ & $\begin{array}{l}0.02 \\
0.00 .5\end{array}$ & $\begin{array}{l}0.05 \\
0.03\end{array}$ & $\begin{array}{l}0.10 \\
0.06\end{array}$ & 0.03 & $\begin{array}{l}0.02 \\
0.02\end{array}$ & $\begin{array}{l}0.028 \\
0.008\end{array}$ & $\begin{array}{l}.40 \\
0.12\end{array}$ & 8.80 \\
\hline 電気銅々転淿 & 0.1 & 10 & 99.99 & 0.0000 & 0.0000 & & 0.0002 & 0.0005 & 0.0000 & 0.0000 & 0.0009 & & \\
\hline 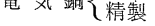 & 0.1 & 7 & 99.99 & 0.0000 & 0.0000 & 0.0005 & 0.0001 & 0.0002 & 0.0000 & 0.0000 & 0.0005 & & \\
\hline
\end{tabular}

通電が出来るようになつた。このために直流電源として は在来の $900 \mathrm{~kW}(150 \mathrm{~V}, 6000 \mathrm{~A})$ と $750 \mathrm{~kW}(135 \mathrm{~V}$, 5555A）を並列運転をするようになつた。

\section{5. 操業成績の概要}

\section{$5 \cdot 1$ アノード精製操業の 1 例}

1) 物量収支 (第7 表)

2）精製アノード月平均品位の 1 例（第 8 表）

3）工程別品位の 1 例（第9 表）

4 ） カラミの成分の 1 例（第10表）

5 ）精製作業例（第11表）

6) 原 単 位 生松丸太 重油精 製 0.10 石/ $\mathrm{t}$ アノード

保 温
合計

$22.9 l / \mathrm{t}$ アノード

$17.6 l / \mathrm{t}$

$40.5 l / \mathrm{t}$

7) 精製実収率 (\%)

. Au 99.99 Ag 99.98 Cu 99.98 Se 94.50 Ni 92.00

\section{$5 \cdot 2$ 電解操業の 1 例}

1) 転炬アノードと精製アノードとの操業成績比較 (第12表)

2）アノード，電気銅分析品位の 1 例（第13表）

\section{$5 \cdot 3$ 考察}

\section{（1）アノード精製}

精製工程に扣いて要する主なる経費は重油，松丸太沶 よび煉瓦等であるのでこれらの経費節減にはとくに留意 している。

重油は炉壁よりの熱損失を防ぐため断熱材の使用試験 を行つているが好成績をあげている。また排煙中の熱回 収に余熱ボイラーを設置しているが，これから使用重油 の30\%の熱量を蒸気として回収している。

精製炉に使用する煉瓦は操業当初は全部高品位のマグ ネシヤ煉瓦を使用した。ところがバーナーロ，装入口， 天井部はスポーリングが激しく寿命が短かかつた。その 後全部クロマグ煉瓦に切換光良好な成績を収めている。 天井部, 装入口, バーナー口, カラミ引旧耐スポーリ ング性クロマグ徚瓦でメタルライン部は耐蝕性のクロマ グ徚瓦を使用している。とくに胴部全体に特殊な断熱煉 瓦を使用し重油使用量を20\%節減した。炉の命数はおが むねつぎのような寒績がえられた。

$\begin{array}{ll}\text { 胴 部 } & \text { 精褩銅 } 3 \text { 万 } \mathrm{t} \text { 以上 } \\ \text { 装 入 } & \text { 精製銅 } 1.2 \text { 万 } \mathrm{t} \\ \text { バーナーロカラミ引口. } & \text { 精製銅 } 1.2 \text { 万 } \mathrm{t}\end{array}$

松丸太は地域的に運搬が不便であるので，松の鮮度が 落ち不利である。10尺物を使用している。

\section{（2）電 解}

転炉アノードより精製アノードになつて, 電解操業上 合理化された点は主につぎのよらなものである。

電解槽 1 榑当りの生産能力が電流の増加, 電流効率の 向上で $40 \%$ 问上した。すなわら電流については 1 槽当り のアノードを33枚（アノードピッチ $135 \mathrm{~mm}$ ) より41枚 (アノードピッチ $110 \mathrm{~mm}$ ) ないし45枚（アノードピッ チ $100 \mathrm{~mm}$ ） に増加することが出来たので電流を $6100 \mathrm{~A}$ より $8500 \mathrm{~A}$ に増すことが出来るようになつた。また電 流效率はアノードピッチの短縮にもかかわらず3〜4\%上 昇した。

槽電圧は電流密度が高くなつてもアノードピッチの短 縮でか觉つて低下している。このため電流效率の上昇と 相まち電解電才便用量がかなり減少した。

残基銅生成率は転炉アノードの $22 \%$ よ 16〜17\%に減 少した。このため残基銅鋳返えしの負担が軽減されるこ とになつた。生成率減少の理由としてはアノード重量の 増加, 電解中の溶解が均一に行われる.ことなどを挙げる ことが出来る。

アノードスライムの生成率は 1.6\%より $1.2 \%$ に減少 し，なたその性状も処理しやすいものとなつた。生成率 の減少, 性状の改良はスライム処理工場の負担を軽減す るばかりでなく大きな合理化がもたらされることになつ た。これについては詳しく後述する。

\section{6. 合理化発展事項の概要}

\section{1 アノード精製操業に伴う合理化事項}

\section{（1）転炿能力の增加}

鋳銅時の待時間が必要でなくなつたので転炉の操業時 間が短縮されるようになつたこと，製銅工程で発生する 繰返物の減少したこと，执よび鋳銅歩留の向上したこと などで転炬の能力は約 $10 \%$ 向上し，アノード精製による 増加経費はかなり抑制された。

(2) その他

アノード鋳造後の手入整装汇要する工数の減少，アノ 一ド形状のよくなつたことによる運搬の容易，大阪製徚 

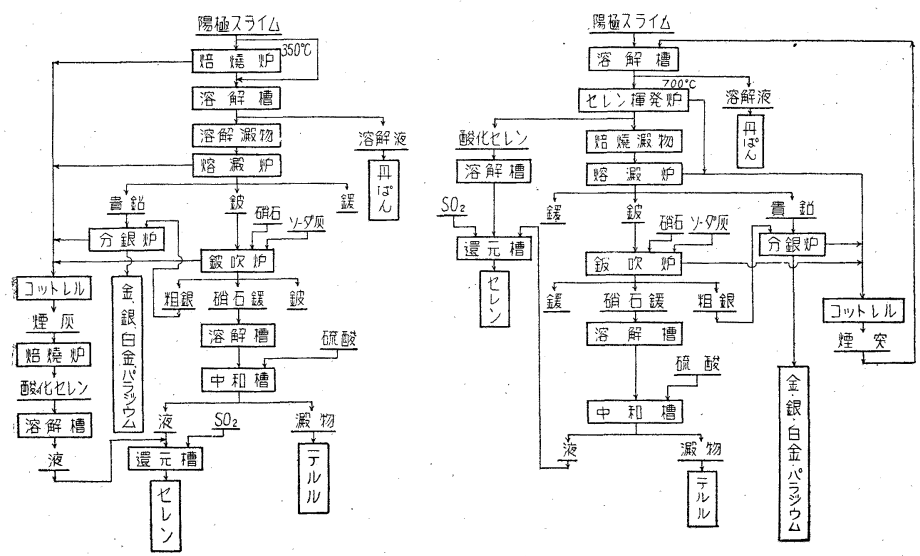

第 11 図 分銅澱物処理方法の改良

所への輸送途中の手析廃銅品の根絶，アノード品質の均 一化による分析試料数の減少などにより相当の経費節減 となつた。

\section{$6 \cdot 2$ 電解操業に伴う合理化事項}

\section{（1） 分銅澱物処理}

従来転炬アノードスライムの脱銅法はスライムを 350 $\sim 400^{\circ} \mathrm{C}$ で焙焼し $\mathrm{Cu}$ を酸化し銅電解液で浸出し脱銅ス ライム中の $\mathrm{Cu}$ を $0.5 \%$ 以下にする方法であった。るし これを焙焼しないで浸出すると3〜 4\%の Cu が残り脱銅 が十分に出来なからた。

精製アノード電解法に切換えてからアノードスライム の性状が変り，アノードスライムをそのまま銅電解液を もつて等気を吹さ込みながら浸出して $0.5 \%$ まで下げる ことが出来るようになつた。このため現在はこの方法に 改め浸出作業を行つている。

この改良によつて設備の改変をほとんど行わないでス ライム中の $\mathrm{Se}$ 回収法の改良, 中間生成物の減少など予 期以上の成果が挙げられた。さらにまた最近新しい処理 方法の研究に成功, 近く工業化の予定であるがこれが実 施の段階に入れば画期的な成果が収められるもの之期待 している。

第11図にアノードスライム処理の従来の方法と現在の 方法を示す。これにしたがいSe 回収につき概要説明す る。従来の方法はまずアノードスライムを $350 \sim 400^{\circ} \mathrm{C}$ にて焙焼し分銅液で浸出脱銅し愹洪炉で Se を鈹中に収 め，この鈹をチリ硝石とソーダ灰との混合物で加熱処理 を行うと Se は亚セレン酸ソーダとなつてカラミ中に集 まる。これを熱湯で浸出し互セレン酸ソーダ溶液とし， 精製し， $\mathrm{SO}_{2}$ ガスで還元して金属セレンを回収する工程 が主流で，その他の Se は注とんど全部ュットレル収麘 装置の煙灰として捕集し，この煙灰を焙焼して $\mathrm{SeO}_{2}$ と して昇華回収していた。この方矤の Se 総合実収率は70 \%でめつた。
これに対し現在の方法はスライム を前述した通りそのまま溶解槽で空 気を吹さ込みながら分銅液にて $\mathrm{Cu}$ を溶解除去した後 $700^{\circ} \mathrm{C}$ にて焙焼し $\mathrm{Se}$ の約80〜90\%を揮発し $\mathrm{SeO}_{2}$ と して捕集する。この $\mathrm{SeO}_{2}$ と焙焼ス ライムの処理よりえられた亜セレン 酸ソーダより金属セレンの回収が行 われるが，Se の総合実収率は 90〜 93\%である。

このように Se の実収率が70\%よ り90〜93\%に向上したが，この汪か 熔澱工程京での半製品が半隇してか なりの収益が兴りスライム処理費と しては25〜30\%の節減となつた。また $\mathrm{Au}, \mathrm{Ag} の$ 実収率 が向上した。

\section{（2）分銅廃液処理}

銅電解液の清浄でアノード中の不純物の内一般に問題 になるるのは $\mathrm{Ni}$ と $\mathrm{Fe}$ である。 Fe については精製工 程に执いて70〜90\%を除去して 0.005\% 位までになつて いるから汪とんど問題价らない。 $\mathrm{Ni}$ はほとんぞ損失 されないでアノード中にあり，転师アノードの場合より 飞電解液に溶け易くなつている。 $\mathrm{Ni}$ の電解液に対する 溶出率は転炬アノードの $90 \%$ に対して精製アノードは98 \%以上である。 $\mathrm{Ni}$ の回収については精製工程の追加で 一応回収率の低下が予想されるが総合的に考察すれば汪 とんど問題にならないようである。分銅廃液の量を転炉 アノードの時の約 $/ 2$ 亿減らしても電解液中の主な不純物 は Ni 12 15g/l, Fe 0.3 0.8g/l, As 2 5g/l (転炬了 ノードの時は Ni6〜 $8 \mathrm{~g} / l$, Fe 2 3g/l, As $2 \sim 3 \mathrm{~g} / l)$ と なり電解にはなんら支障を来たさないので分銅廃液処理 そついての設備上, 経費上の負担が軽减されることにな つた。

\section{（3）残基銅熔解反射炕の負担軽減}

残基銅生成率が精製アノードになつて23\%より 16〜17 \%に減少したので反射炉に加わる負担が軽减し電錬費は かなり軽減された。これをいい換光れば反射炬の能力が そのまま約 $30 \%$ 増加したことになるのて電気銅增産起業 工事の経費節減には少なから奴貢献をした。

\section{（4） 3600t 起業計画の促進}

䀡和31年夏比島トレド釷を增処理する事に契約が締結 されたので，直島製煉所の製鍊能力を粗銅月産 $3000 \mathrm{t}$ ， 大阪製煉所を電気銅月産最大 $3000 \mathrm{t}$ の能力とすること になつた。これを転炉アノード法にて実施しょうとする と非常に高い起業費と長期の工事期間を要し，多分この 計画は非常に困難なるのとなつたに違いない。しかしす でに精製アノード電解法を採用していたので，大阪製煉 
所の電解工場は 120 槽の堌槽のみにてすみ，アノードス ライム処理設備特よび分銅廃液処理設阷はまつたく工事 を必要としないで，大部分が直島製煉所関係の工事のみ となつた。しかも工事期間は昭和31年12月洋工してわ ずか 12 力で全工事を完成するといらように万事きわめ て容易に $3000 \mathrm{t}$ 起業工事を運ぶことが出来たのはまつた く精製アノード電解法の效果といっても過言ではない。 工事費の内容は概略つぎの通りである。

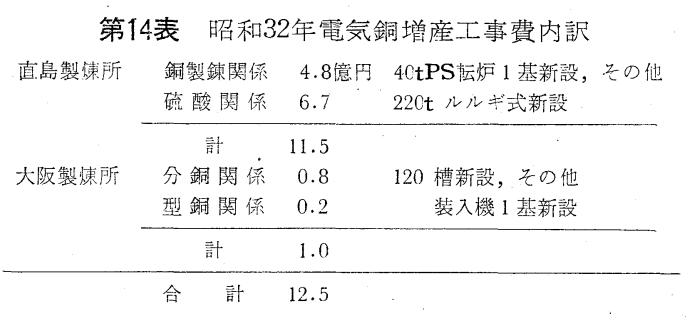

\section{7. 起 業 効 果}

以上粗銅の精製杼よび精製アノードの電解について概 要を述べてが，その起業效果をここに要約する。

（1）增蓙工事費の軽減

昭和30年，昭和 32 年と. 2 度の相次ぐ増掂起業工事が短 期間で, 少額の工事費で，乙かも比較的容易に完成した ことはまつたく精製アノード電解法の採用によるるので ある。

\section{（2）製銇費の軽減}

電錬費の軽減と電錬工程以降の合理化によつて，ア， 一ド精製のための増加整銇費は十分償われ総合製錬費と してはかなり減少した。現在な和精製アノード電解法の 特徵を生かすための研究が続けられているのでさらに製 鋉費は減少ずるるのと期待している。

電気銅 $\mathrm{t}$ 当り製鍊質を指数をもつてあらわすと第15表 のようになる。

第15表 電気銅 $\mathrm{t}$ 当り製錬費比較

\begin{tabular}{|c|c|c|c|c|c|}
\hline 原料アノードの種類 & 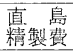 & $\begin{array}{l}\text { 大阪 } \\
\text { 分銅費 }\end{array}$ & 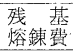 & $\mid$\begin{tabular}{|l} 
スライ公 \\
䞨理賈
\end{tabular} & 合 \\
\hline $\begin{array}{l}\text { 転炬銅による場合 } \\
\text { 制製銅化上る徣会 }\end{array}$ & $\overline{18}$ & $\begin{array}{r}100 \\
74\end{array}$ & $\begin{array}{l}17 \\
13\end{array}$ & $\begin{array}{l}34 \\
26\end{array}$ & $\begin{array}{l}151(100) \\
131(87)\end{array}$ \\
\hline
\end{tabular}

（3）实収率の向上

直島䑩銅工程以降の $\mathrm{Cu}$ 実収率が $0.1 \%$ 以上向上した。 他の金属 $\mathrm{Au}, \mathrm{Ag}, \mathrm{Ni}, \mathrm{Se}$ などていても同様いくら
か実収率は向上したようである。

（4）転炉能力の增進

転师操業時間の短縮, 繰返物の減少で約 $10 \%$ 能力が増 進した。

(5) 電解槽 1 槽当能力の增進

アノードピッチの短縮, 電流効率の向上, 電法密度の 上昇などで約 $40 \%$ 能力が增進した。

（6）分銅澱物ならびに分銅廃液処理の簡素化

アノード精製工程の付加でアノード中の $\mathrm{S}$ 拉よび $\mathrm{Fe}$ が非常に少なくなつた。このため分銅澱物は処理し易い 性状となり，分銅廃液は少なくて済むようになつた。こ のため分銅潵物処理工程は非常に改善され，分銅廃液処 理工程の負担は軽減された。

（7）残基銅愹解反射炬の負担軽隇

残基銅生成率が精製アノードになつて23\%より16〜17 \%に減少した。ごのため残基銅愹解反射炉に加わる負担 は軽隇された。

（8）製品品質の向上

転炉アノードよりは容易に光られない高純度の安定し た製品がえられるようになつた。このため優良なる棹銅 がえられるようになり，銅荒引線品質も向上した。さら に無酸素銅の大量生産が容易之なり, 将来の発展が大い に期待されるようになつた。

\section{8. 結言}

諸外国に招いてはすでに古くから行われているが，本 邦に拉いては従来採算的に有利なものではないと考兄ら れ久しく採用するに到らなかつた。この精製粗銅の電解 をここに害際操業に执いて予期以上の多大の娃成績を収 めることが出来た。筆者としてこれに過ぎたよろこびは ない。

この成功はもちろす到底 $1 ， 2$ の人の力でなしらる筈 のものではなく，会社主脳部の理解と英断技よび先輩各 位の御䩒檤撻の賜であることはもちろん，また直接試験研 究拉よび起業の完成とその後の運営に筆者と学苦をとも にした技術者各位の努力等，これ関係した多くの人々 の協力に負うものであることをここに強調し，この機会 にこれらの人々に対し深甚なる敬意と感謝の意を捧げた い。 